\title{
Discursive Problematisation of Marital Rape from an Intercultural Perspective: An Empirical Analysis
}

\author{
Susanne Nef ${ }^{*}$
}

\begin{abstract}
Violence against women is one of the main social problems worldwide. Marital rape and its recognition are discussed as a new boundary mark because of greater social sensitivity on violence. From an intercultural social work perspective, it is highly relevant to learn more about perceptions of different kinds of violence in order to plan adequate interventions. The article presents findings from expert interviews related to the perception and the intervention structure contextualised by the discourse on marital rape in India. It concludes six main implications for intercultural social work. The main finding (6) states that in all of these settings, the role of the family system should not be underestimated, and whenever possible couple counselling should be considered. Viewed against the background of the highly individualised Swiss society, this is a finding, which needs to be taken into careful account in Swiss intercultural social work.
\end{abstract}

Keywords: Social work, Intercultural research, Marital rape, Perceptual patterns

\section{Introduction}

As exemplified by the social problem of marital rape, the study aims to gather empirically based insights and potential

* Zurich University of Applied Sciences (Switzerland), School of Social Work, Institute for Diversity and Participation, susanne.nef@zhaw.ch 
implications for interventional planning in intercultural social work. At a time when migration processes shape European national politics, and as European societies grow more heterogeneous, it is of great relevance to learn more about different perceptions of social problems to identify potential barriers. It is done with the aim of addressing and reaching the heterogeneous group of clients in a given country, and to plan adequate interventions. Against this background, intercultural social work is understood as any form of 'domestic social work' with culturally diverse clients (Nagy \& Falk, 2000) and as social work focusing on issues of global concern and ways in which these have to be addressed at the domestic level (Gray \& Fook, 2007). According to this understanding of intercultural social work, it includes all social work practices within a migration context, addressing social problems in the social worker's country of practice. Therefore, the article seeks to contribute to an understanding of the social influences constructing the social and individual perception and interpretation of violence.

\section{Structure}

The article presents first an overview of the international results of violence against women. Second, it discusses the social issue of marital rape $^{1}$ as a concept. Third, it presents the theoretical framework and analytical approach employed, including the role of the new discourses through media. Fourth, it gives an overview of the data and methods of the study as well as of the discourse on the process of the jurisdiction of marital rape in India to contextualise the findings of the expert interviews, whose findings are presented in the next section. Fifth and finally, it outlines the main findings related to implications for intercultural social work and closes with a brief discussion regarding actionable recommendations for Swiss intercultural social work and intercultural research.

\section{Violence against women}

According to country data from WHO (2016), about one in three women worldwide have experienced either physical and/or sexual intimate partner violence or non-partner sexual violence in their 
lifetime. WHO (2013) states that besides being a social problem, violence against women is also a "global health problem of epidemic proportions" and defines violence against women as "any act of gender-based violence that results in, [...], physical, sexual or mental harm or suffering to women, including threats of such acts, coercion or arbitrary deprivation of liberty, whether occurring in public or private life" (WHO, 2016). In addition, WHO (2016) views sexual violence as "any sexual act [which] attempts to obtain a sexual act or other act directed against a person's sexuality using coercion, by any person regardless of their relationship to the victim, in any setting." As WHO (2016) concludes, most of this violence is intimate partner violence: worldwide, at least one-third of women who have been in a relationship report that they have experienced physical and/or sexual violence by their intimate partner (WHO, 2016). According to UN Statistics (2015), prevalence is generally high in Africa (one-quarter of countries reporting prevalence of at least 50\%); in Europe, more than half of countries report a lifetime prevalence of at least $20 \%$, and in Oceania, prevalence is reaching over $60 \%$ in a number of countries. Barker et al. (2011) discuss men's reports of perpetration of sexual violence against women and arrive at a figure ranging from 2\% (Brazil) to $25 \%$ (India) and against a female partner from 1\% in Brazil to $20 \%$ in India.

\section{Social problems as socially and historically constructed: the example of marital rape}

The data on prevalence shows that violence is a worldwide social phenomenon. However, violence was not always the concern that it is nowadays in global as well as in local discourses (Brown, 1979). Scholars explain the change as one of social redefinition by expansion of the social category of violence (e.g. Reiss \& Roth, 1993). In social-scientific research, the social and legal recognition of marital rape is therefore seen as an indicator for the multidimensionality of 'violence' as a social phenomenon in the context of social reality. In general terms, social phenomenon becomes social problems once they are socially perceived and defined as acts and conditions that violate the norms and values found in a specific society (Eitzen, Zinn, \& Smith, 2014). Therefore, 
social phenomenon becomes social problems and even receive legal recognition through a process of social construction. The same social phenomenon may be considered as a social problem and a specific behaviour related to this phenomenon can be deemed criminal in one society but a common act in another society, or in the same society at a different time (Rosenfeld, 2009). Specifically, the family environment is viewed as an example where this change is seen: in various social contexts worldwide, as "the violent male was seen as enforcing a natural rule that men should direct the activities of their wives and children" (Blume, 1996). This example shows the historical and social dimension of violent acts, which were integrated into society by justifying such violent actions. By the 1980s, the second feminist movement emergent initially in the US had raised public awareness of rape issues. Hence, social recognition increased and as a result of changing social attitudes, statutory changes were enacted in many countries that redefined rape and introduced the concept of sexual assault, thus creating different degrees of rape (Parrot \& Bechhofer, 1991).

Research and social discourses have therefore gradually led to an environment in which ever more people in various contexts agree that sexual violence in general and sexual violence in intimate partnerships (such as marital rape) in particular are forms of violence (Blume, 1996). Exemplarily, as the perpetrator image has changed (from the image of 'stranger rape' to growing awareness of 'acquaintance rape'), the social and legal perception of an offence also underlie the continuing social change in time (Johnson \& Sigler, 2000). As Clark and Lewis (1977) note, rape in various countries and contexts was originally perceived as an act against the father or husband of the victim. Thus, it is the changing of social assumptions that has led to the legal recognition of marital rape in many countries within the past 20 years. According to UN Statistics (2015), 54 countries have passed laws on marital rape. These social and legal changes can be seen exemplary and as new border demarcations because of greater social sensitivity on violence. Still, the social perception of marital rape differs from the perception of sexual violence committed by 'strangers' in public places. Nevertheless, this perception is based neither on the consequences of the rape (such as the trauma the victim undergoes) nor on the offence itself. Thus, studies imply that particularly the 
intimate relationship between victim and offender causes serious harm and traumatisation. Apart from physical injuries, direct consequences may be the general loss of confidence as well as the loss of feeling of safety in one's own intimate social environment. Moreover, due to the intimate relationship, the victim may be exposed to sexual violence over a longer period, which may cause an enduring trauma (Boucher, Lemelin \& McNicoll, 2009). As Hanneke and Shields (1983) discuss, this circumstance may increase the feelings of humiliation, isolation, and helplessness. It can strengthen symptoms of depression and lead to self-destructive behaviour patterns, and suicidality (Boucher et al., 2009).

\section{Theoretical framework and analytical approach: social constructionism and sociology of knowledge (framed by the linkage between social constructionism and symbolic interactionism)}

From the social-constructionist perspective, an act or behaviour such as domestic violence and marital rape become a social problem through a process of successful claims-making by social movements. According to Rosenfeld (2009), groups or social movements advance in this process a particular definition of a problem and seek to mobilise particular kinds of social response (such as legal recognition). Unlike other approaches to discourse, as interpreted by Keller (2010), "the analysis of knowledge [...] [is] thereby pulling 'discursive struggles' into the focus." Moreover, a social constructionist perspective on social problems, and principally symbolic interactionism as a theoretical framework sees society as the product of individuals interacting with one another (Charon, 2010). It thereby allows the analysis of the processes of interaction and negotiation of patterns of interpretation, perception and social actions between groups or individuals in relation to social discourses, patterns of interpretation and processes of change.

5.1 The role of emergent and new discourses through new-generation media

Thus, the legal status of a behaviour-whether it is defined as a crime or not-lies from a symbolic-interactionist perspective in the 
social response to the behaviour or to the persons who interact in a specific situation rather than in the content of the behaviour itself (Rosenfeld, 2009). Therefore, changes in the legal status of a behaviour can occur because of new perceptions and definitions of a social phenomenon. Definitions of violence are seen consequently as value judgements, which are often put forward by social movements (Rosenfeld, 2009). Nowadays, these social movements utilise the media to disseminate and project the issues they wish to raise. As a result, (re)definition processes are influenced and characterised by particular attention processes in the media. Specifically, the internet plays an important role in processes of changing of social assumptions: social media, for instance, function through the internet to break down the rigid boundaries between producers and recipients of knowledge. Due to its accessibility and growing popularity, social movements, as well as individuals and groups, often address new issues on social media or the internet. Therefore, new processes oriented to problematising social phenomena are frequently initiated on the internet. This allows for an ethnographic approach, which forms the basis of empirical research on the internet, to follow the same route as users did (search engines constitute the survey instrument).

\subsection{Discourses from a perspective of the sociology of knowledge}

Against this background, in the present study, discourses are conceptualised as a set of meanings, rules and (social) practices that are manifested in language use. This methodology aims to open a window onto how certain knowledge systems gain hegemony over others. Therefore, discourse analysis is interested in the processes of the production and reproduction of meaning and knowledge (Parreiro \& Rinne, 2015).

\section{Contextualised description of methods and data}

The expert interviews were based on the reconstruction of the discourse on marital rape in India. The selection of the experts was done according to the insights gained during the research phase of the reconstruction of the discourse on marital rape. Therefore, the data of the reconstructed discourse was used to develop the qualitative sampling methods and the survey instrument for the 
expert interviews. The criteria for the selection of experts was based on the understanding of 'experts' according to Meuser and Nagel (2013): experts as actors with a specific role perception, with a specific function within a social system, and who played a role within the discourse, and therefore set the agenda and shaped public perception. Specifically, experts were identified based on their role as discourse actors ${ }^{2}$.Their function within institutional contexts was confronted by affected clients (marital rape). Consequently they possess knowledge about the client group as well as about institutionalised processes. The seven experts interviewed were from different interdisciplinary fields (social work, gynaecology, law, social movements): outpatient counselling \& prevention, research \& teaching, women's shelter, and clinical social work in the urban areas of Mumbai and Bangalore.

\section{Overview of the discourse}

Thirteen days earlier and parallel to the ongoing discourse of sexual violence against women in public spaces in India, which was leading to a new level of social and political recognition of this social problem at the end of 2012, social movements used the internet to demand equal social and legal recognition of marital rape in India. Therefore, the discourse analysis was conducted for a specified period of study $(03 / 12 / 12-31 / 07 / 13)$. For this period, 118 documents (internet documents, scientific publications), 245 print articles and 30 official policy documents were analysed exploratorily and reconstructively.

7.1 Problem career: problem development, problem history and relevant discursive events

During the eight-month period of study, the problem called 'marital rape' was gaining more visibility and recognition. Before that period, marital rape had been a topical focus 16 times in different articles extending over 19 years (from 1993-2012). In 1993, for example, 'marital rape' was mentioned for the first time in the Indian novella The Binding Vine. ${ }^{3}$ In February 2007, for instance, the UN Committee on the Elimination of Discrimination against Women had recommended to India to "widen the definition of rape in its Indian Penal Code (IPC) to reflect the realities of sexual 
abuse experienced by women and to remove the exception of marital rape from the definition of rape" (CEDAW Committee, 2007). The first discursive event (3/12/12), involving a man acquitted by a Delhi court on charges of raping his wife), advanced the perception of the problem. Since the defence counsel argued that the IPC does not recognise any such concept of marital rape, the court decided on the ground that having sexual relations with his spouse, even forcibly, does not amount to 'marital rape'. Consequently, "sexual intercourse with her by accused would not constitute offence of rape even if it was by force or against her wishes"(Times of India, 2012a). ${ }^{4}$ In mid-December 2012, after the occurrence of the second discursive event (Nirbhaya rape on 16/12/12), the mass media again published articles concerning marital rape. Because Women's rights movements claim the need for legal recognition and thus for eliminating the exception contained in Section 375 on rape in the IPC: "Sexual intercourse by a man with his own wife, the wife not being under 16 years of age, is not rape"(Sec. 375. Rape, 1973). By this claim for elimination of the marital rape exemption clause, the women's rights movements demanded an extension of the guarantee of equal protection to married women. Through this demand, the movements were seeking to address the broader political-administrative system. From the mid- to late December 2012, 27 articles about marital rape were published. These articles made clear reference to the ongoing discourse on sexual violence in public spaces: for instance, by arguing to "[f]orget roads and public transport. Married women in India are helpless even in their own bedrooms. For, the Indian Penal Code (IPC) does not even categorise 'marital rape' or 'forced sex by husband' as a cognizable offence" (Times of India, 2012b). In January 2013, marital rape was a focal topic in 62 articles. This can be explained by a new event-on the report on 23 January by the Justice Verma Committee (JVC). This three-member Committee, Verma, former Chief Justice of the Supreme Court (head), Justice Leila Seth, former judge of the High Court, and Gopal Subramanium, former Solicitor General of India, was constituted on 23 December 2012 with the aim to recommend amendments to the Criminal Law (e.g. to quicker trial, enhanced punishment for criminals accused of committing sexual assault against women) (PRS, 2013). With regard to marital rape, Verma, Seth, and 
Subramanium (2013) recommended deleting the rule stipulating that marital rape must only be considered a crime in cases when the wife is younger than 16 or a couple is judicially separated. Therefore, Verma et al. (2013, p. 113) outlined that the "exemption for marital rape stems from a long out-dated notion of marriage which regarded wives as no more than the property of their husbands" and recommended to the PM the elimination of the exception.

\subsection{Problem interpretations and different levels of discourse}

On the academic level, the discourse actors refer to the need to recognise rape as a crime against the physical integrity and humanity of the individual regardless of the relationship between perpetrator and victim. The hegemonial discourse strategy of scholars is to discuss the recognition of the concept martial rape against the background of human and individual rights. Gupta and Gupta $(2013$, p. 31) even state that the individual rights framework might be the way to challenge cultural assumptions: "In western countries, activists have operated within the individual rights framework in seeking to challenge cultural assumptions about marital relationships. The individual rights paradigm may have a similar role in India, where cultural assumptions prevent communities and even women's organisations from talking about the evil of marital rape" (Gupta \& Gupta, 2013, p. 31). As Pandey (2013) argues: "In fact, the incidents of marital rape are totally against basic human rights which are provided to every individual by birth". Furthermore, Gupta and Gupta (2013, p. 31) point out "it is argued that marital rape should be criminalized in India, as this can be achieved by applying an individual rights approach to violence against women. Indian women's organizations have succeeded to achieve public awareness and to pass legislation on domestic violence, but marital rape has not been fully criminalized by abolishing the distinction between marital rape and "stranger" rape. But marital rape will neither be criminalised nor punished until legislators and the society acknowledge women's individual rights within the marriage." Likewise, scholars' problematise the marital rape exemption by underlining the (individual) consequences of it: "Rape within marriage is a concept that agonises the wife to the very core. The dread of having to face it 
and still have to silently suffer through it is an unbearable thought that affects the psyche of the women. This self-enforced silence has a very detrimental effect on the emotional, psychological and mental stability of women. However, this silence is not exactly selfenforced. The lack of laws and abundant social stigmas against the act of marital rape is one of the primary reasons that the evil of marital rape is still hidden behind the sacrosanct of marriage". (Gupta \& Gupta, 2013, p. 16)

Due to the claim for legal recognition, the discourse actors have to concurrently address two different arenas (society \& politics), which have parallel dichotomous discourses and interests. This results in two main counter-discourses and alternative interpretations of the problem:

(1) Discourse actors who recognise the concept of marital rape and thus its existence as a social phenomenon, but with an alternative interpretation of marital rape and/or its suitable interventions

For instance, such as the recognition of the existence of marital rape as a social phenomenon while questioning the need for the elimination of the marital rape exemption. Hence, doing so by arguing that "the demand was also partially accepted in the Domestic Violence Act 2005, as it is considered a domestic violence of a sexual nature under DV ACT, but is not yet defined as rape in any law"(Times of India, 2013c). Furthermore, it is argued by discourse actors who recognise the concept marital rape but emphasise that the current legal situation already takes it into due account: "Apart from this, divorce laws provide for cruelty as a ground for divorce. The act of forced sex, causing mental and physical trauma to a woman, will entitle her to get a divorce. Divorce has often been sought and granted on account of marital rape causing extreme mental trauma and cruelty. Marital rape remains fairly comprehensively covered in the Indian legal system" (The Indian Express, 2013b).

On the other hand, discourse actors question if a legal recognition by itself may be sufficient: "Beyond the what-punishment-forrapists debate are voices pointing towards rape within homes. And the fact that rape is the most vicious, but by no means the only, 
form of violence that women experience in their daily lives. It is therefore rightly being suggested that a more comprehensive approach is needed to address the issue of rampant gender violence. Yes, the police, the politicians and even the judiciary must be held to account. But what about our own complicity, our own patriarchal mindsets?" (The Indian Express, 2013a). Furthermore, discourse actors (primarily journalists and social activists) tend to problematise the non-recognition of marital rape by culturalising it: "In a culture that continues to confer on women 'owned' status (property of father/husband), their right of refusal in marriage-to dowry, intimidation and even sex, is unsettling for society" (Times of India, 2013a).

\section{(2) Negation of marital rape (negation of the social phenomena itself)}

Primarily, on a political level and in the social media, discourse actors argue against legal recognition by negating the concept. Therefore, one of the hegemonic discourse strategies in the social media is to argue against the background of self-interest of the social movements: "So it is evident that your argument is not only weak but is motivated to create a new business for advocates and other women NGOs" (The Male Factor, 2013). By contrast members of politics argue with reference to the institution of marriage: "Singh [...] justified the government's decision not to include marital rape in the Criminal Law Amendment Ordinance promulgated on February 3, saying that marriage presumed consent" (Times of India, 2013b).

\subsection{Failure of the perception at the political level}

With the onset of the fourth discursive event-the negation (of legal recognition of) marital rape by the state-the content and discourse strategies change noticeably. The focus is no longer on the criticised and problematised social condition (marital rape) but the criticism of non-recognition by the state. The discourse actors are endeavouring to persuade the president, in direct response to the media, to recognise marital rape. In addition, some politicians are addressing the media. For instance, Singh who articulated the government's view that "treating marital 'rape' as a sexual offence would go against the traditional family system in India, where 
marriage is seen as a steadfast institution. It may lead to accusations of rape being made in the wake of marital disputes, causing irreparable damage to the institution of marriage" (Times of India, 2013b). Therefore, discourse actors such as social activists, journalists and scholars started to problematise the underlying concepts and assumptions of this image of the institution of marriage. As Gupta and Gupta (2013, p. 31) problematise the "Ideas about women's sexuality, and therefore ideas about nonmarital and marital rape in Indian society, originate in concept of gender, shame and family honour, rather than women's rights and individual autonomy. If the reformers see rape as a crime against a woman and her person and bodily integrity and humanity, then marital rape and its punishment would be a legal possibility. To bring a change in the existing policy, we may use an individual rights rhetorical approach in working towards criminalizing marital rape in India, because marital rape will not be a State concern until the society and legislators understand women to have individual rights within marriage" (Gupta \& Gupta, 2013, p. 31).

\section{Summary and brief discussion}

The shift in focus from the problematising of marital rape to the problematising of the negation illustrates that the discourse strategies failed. The problem did not reach general social recognition and did not lead to oppositional measures by the state-although general adversarial proposals were directed towards the state and referred primarily to 'right and information' (legal recognition and prevention through information). Above all, the discourse strategy of 'moralisation' failed since the problem actors could not position marital rape discursively as a violation of social norms. If this had succeeded, nobody could have contradicted the emergent problem pattern publicly without exposing themselves to moral-discursive sanctions. Therefore, the perception of marital rape as a problem could not achieve social hegemony nor was it able to exclude counter-interpretations and alternative interpretations. 


\subsection{Demand for criminalisation instead of individual focus}

When the discourse of rape in public spaces reaches the public, actors (primarily women's rights organisations) attempt to position the discourse of marital rape and to create awareness of the problem. A high degree of differentiation was reached by the separation of both discourses (rape in public space \& marital rape). The discourse actors disassembled the phenomenon of rape into sub-aspects. This permits both greater flexibility as well as a broader scope of action (Nedelmann, 1986). However, the failure of the social problem-especially against the background of the successful problem career of the subject of rape in public spaces illustrates that the separation of the two discourses and the disassembly of the social phenomenon of rape were differentiated too strongly; as consequence, the flexibility of action was rather limited: Due to the clear and unequivocal demand for criminalisation, the actors were left with hardly any other action options after the failure of the problematisation at the level of the political-administrative system. This also appears in the movement's focus on the problematisation. After the negation by the state, this negation and primarily this decision were problematisated, while the criticised social circumstances (marital rape) moved to the background.

\subsection{One-sided focus and unspecific description}

In the complete course of the problematisation, there was no clear specification of the problem's causes, the victims and the solutions. Moreover, the dichotomous question of guilt and innocence was generalised: men as perpetrators on several levels (politics, society, community and relationships) and women as victims on the same levels. This representation emphasises marginalisation and role allocation. However, a clear specification of the problem patterns is significant regarding the transition of a latent social problem to a manifest problem. The actors could not fully construct a general attitude that marital rape possessed the characteristics of a social problem. In the absence of this, marital rape is still not considered to be of public interest, but a private matter or - on account of the conjugal rights of husbands - even a non-existent one. 


\subsection{Political decisions and interests}

In the context of political interests, the rejection of the problem of perception could -against the background of new elections in May $2014-$ be seen as populism. Subject settlement occurs when political positions and the values linked to self-interest are supported by theories on political decision-making. Schumpeter (2008), in his theoretical model, reduces the decisions of politicians to the sum of the decisions that protect their political career in the context of subsequent elections. Nevertheless, despite the attempts at explanation being 'male-focussed' and mono causal, they were situated on the rational level-particularly regarding ideological and moral grounds - and demonstrate that political actors make their decisions also as subjects and individuals of their respective societies (Schumpeter, 2008). This thesis is underpinned by the individually applied problem patterns and discourse strategies of the political actors (official statements vs. the appearance of individual statements by political actors).

\subsection{Expert interviews: Field of activity}

The experts emphasise that victims usually do not visit counselling centres. Most women would do so only after four to five years with the intention of changing their husband's' behaviour. The occurrence of massive domestic violence may induce a woman to seek help because this offers her the possibility to report her experiences. Therefore, this particular woman may speak about physical violence rather than the sexual component of the abuse. Due to the fear of social stigma, she may attempt to become accustomed to the violations. According to experts' opinions, interventions are complicated because of the social tabooing of female sexuality. Experts point out, as the greatest challenge for prevention, the social pressure on men- relating to a hegemonial image of manhood. At this point, the experts see several starting points for possible interventions: (1) Support for interaction at the couple level to remove the taboo from the subject of sexuality, (2) Preventive sex education at schools, marriage preparation and parental education courses concerning sexuality, gender role images and perspectives, health and individual rights. In summary, the experts assume that victims accept marital rape. The experts locate the primary cause for this in the fact that women culturally 
and socially cleave to marriage because they are afraid of the social stigmas inherent in separation. However, women also fear the social stigmas attached to breaking the taboo regarding sexual issues and thus dare not speak out. Hence, the experts consider preventive measures as a starting point, with the mid- or long-term goal being a change in social values. In the narrative passages of the interviews, the following potential implications for interventions were elaborated (1) Support for empathy towards the women by a perspective change (beginning with men). (2) Strengthening couple interaction: for equal rights and open conversations about sexuality. (3) Inclusion of peer-educators as multipliers for men as well as the 'bare-foot counsellors' for women (4) Empowerment: strengthening the women's negotiating competence. Women should been abled to assert themselves and demand their rights. (5) Sensitisation and education work focussing on the social sphere and representatives of religious communities. According to the experts, in all of these settings, the role of the family should not be underestimated. Mothers-in-law were mentioned as key players who should be contacted in their mother tongues (6) Taking into account their positions, they should be persuaded that violence is not a desirable solution and is not to be justified, and it is necessary to explain to them that marriages might be saved with the help of the intervention (Expert Interviews, 2013).

\section{Implications for intercultural social work and research}

In intercultural social work, the challenge is that societies have diverging perceptions of social issues. Therefore, research is of substantial salience for intercultural social work, since the individual and social definition or perception of a social issue such as intimate partner violence and marital rape seem to be culturally shaped (e.g. by gender roles) (Chawla, 2004; Fernandez, 1997; Klosterman \& Fals-Stewart, 2006). While these definitions constitute the area of activity of social work and the range of competences of social workers, these divergent definitions might also influence the individual perception of experiences of abuse as well as the use and acceptance of professional help by migrants in their host countries (Klein, 2012). Therefore, the findings outlined 
that social work must increasingly focus on international and transnational discourses and lifestyles in order to obtain access and thus be able to address the individual needs and perceptions of its heterogeneous clients. One possible approach may be based on groups such as the police and working groups from women's shelters, and might be extended to religious representatives in Switzerland, and selected organisations in their respective countries of origin. In this way, potential resources for, and coping strategies, of the affected can be identified and appropriate actions taken. The purpose is to draw conclusions for social work regarding different perceptions and the acceptance of help. Thus, the analysis of the perception, definitions and interpretations of related phenomena in different contexts may help to identify barriers. Although social and political recognition of domestic and sexual violence against women is relatively widespread in many countries, the individual problem perception, as well as its implications on the use and acceptance of professional interventions, is a topic that has rarely been considered. Therefore, it is important that the individual and social perception of social problems and its possible influence on the acceptance of help should be carefully considered during the advisory process, the planning of interventions, and in prevention campaigns. First of all, both the individual needs and problem perceptions must be addressed during the intervention planning process. Moreover, this study identified important emotional and social aspects, such as the importance of considering collective family structures. For example, Switzerland usually offers individual-oriented interventions. For instance, couple counselling in cases of domestic violence is not recommended and therefore for the most part not provided (except in cases of bi-directional dynamics of violence, the violence has already ended, and after the (spatial) separation) (Flury, 2010).

The study showed that problem awareness primarily develops based on social definitions of social issues rather than individual or social categories of consequences. As noted in the introduction, victims of martial rape undergo similar traumatisation as victims of so-called 'stranger rape'. This leads to the thesis that the perception of the offence 'marital rape' is based neither on the consequences of the rape nor on the offence itself. If this were the case, all forms of rape would be perceived as identical. In point of fact, such 
divergent perceptions as manifested in the empirical results can be explained by the fact that they are influenced by prevailing value orientations (Bohle, 2012). It arises in the process of addressing and criticising social circumstances. As shown, taking a sociology of knowledge approach to discourse analysis in examining social problems opens a window on society's salient role in their construction and perception. The culture and cultural identity of a society (e.g. ethnic affiliation) are, from a social-constructionist perspective, understood as social constructs performatively (re)produced through discourses and social actions(Rosenfeld, 2009). Therefore, intercultural research aims to contribute to an extension of knowledge. But asocial-scientific as well as an intercultural social work perspective clearly suggest that analyses directed at a particular country might problematise a particular group or culturalise and essentialise a specific social problem (here: marital rape). Therefore, it is important not to generalise through cultural essentialism and gender essentialism (gendered vulnerabilities). A focus on specific groups may cause clients from other backgrounds and members of the majority society to receive less attention. As a result, such a focus might result in 'selective labelling', marginalising people and obscuring the fact that not all members of a specific group confront these problems. Nonetheless, specific knowledge can help to provide targeted and effective prevention and intervention work. Thus, it can help to identify and explore barriers to provision of assistance for clients in Switzerland and to plan the interventions in a corresponding differentiated manner. Additionally, it might support reflections on intercultural social work frameworks, and initiate learning processes in which social workers and social work students can "continuously examine, challenge, question, and expand their cultural assumptions"(Lee \& Greene, 2004).

${ }^{1}$ In the following, with the aim of stressing how perceptions of social problems are not oriented to criminal offenses but rather are contextrelated and shaped by social and historical factors, I speak intentionally of marital rape (instead, for example, of sexual assault or sexual violence). This is done in order to point to the context of intimate relations, including the legal status of the institution of marriage, which influence the patterns of interpretation of rape and marital rape. 
2 Discourse actors: discourse participants who were active as opinion formers.

3 Deshpande, S. (1993). The Binding Vine. Virago new fiction. London: Virago.

4 The quotes function as anchor examples.

\section{References}

Barker, G., Contreras, M., Heilman, B., Singh, A., Verma, R., \& Nascimento, M. (2011). Evolving Men Initial Results from the International Men and Gender Equality Survey (IMAGES). Retrieved from ICRW website: https://www.icrw.org/wp-content/ uploads/ 2016/10/Evolving-Men-Initial-Results-from-the-International-Menand-Gender-Equality-Survey-IMAGES-1.pdf

Blume, W. T. (1996). Social Perspectives on Violence, 2(1), 9-23. Retrieved from https://quod.lib.umich.edu/m/mfr/4919087.0002.102/--socialperspectives-on-violence?rgn=main;view=fulltext

Bohle, H. H. (2012). Angewandte Sozialforschung und soziale Indikatoren. In G. Albrecht \& A. Groenemeyer (Eds.), Handbuch soziale Probleme (pp. 1349-1384). Wiesbaden: Springer VS. https://doi.org/ 10.1007/ 978-3-531-94160-8_32

Boucher, S., Lemelin, J., \& McNicoll, L. (2009). Marital rape and relational trauma. Sexologies, 18(2), 95-97.https://doi.org/10.1016/ j.sexol. 2009.01.006

Brown, R. M. (1979). Historical patterns of American violence. In H. D. Grahman \& T. R. Gurr (Eds.), Violence in America: Historical and comparative perspectives (pp. 19-48). Beverly Hills: Sage.

CEDAW Committee. (2007). Concluding comments of the Committee on the Elimination of Discrimination against Women: India: Thirtyseventh session 15 January-2 February 2007. Retrieved from www.un.org/.../daw/.../India/India \%20-\%20CO-3.pdf

Charon, J. M. (2010). Symbolic interactionism: An introduction, an interpretation, an integration (10th ed.). Boston: Prentice Hall.

Chawla, S. (2004). India. In K. Malley-Morrison (Ed.), International perspectives on family violence and abuse. A cognitive ecological approach (pp. 265-281). Mahwah, N.J.: Lawrence Erlbaum Associates.

Clark, S. M., \& Lewis, D. J. (1977). Rape: The price of coercive sexuality. Toronto: Women's Educational Press.

Eitzen, D. S., Zinn, M. B., \& Smith, K. E. (2014). Social problems (Thirteenth Edition). Boston: Pearson. 
Fernandez, M. (1997). Domestic Violence by Extended Family Members in India: Interplay of Gender and Generation. Journal of Interpersonal Violence, 12(3), 433-455. https:/ / doi.org/10.1177/088626097012003008 Flury, R. (2010). Grundsätze der Beratung gewaltbetroffener Frauen. In M. Weingartner (Ed.), Prävention und Gesundheitsförderung. Häusliche Gewalt erkennen und richtig reagieren. Handbuch für Medizin, Pflege und Beratung (2nd ed., pp. 123-130). Bern: Huber.

Gray, M., \& Fook, J. (2007). The quest for a universal social work: Some issues and implications. Social Work Education, 23(5), 625-644. https://doi.org/10.1080/0261547042000252334

Hanneke, C. R., \& Shields, N. M. (1983). Batered wives' reactions to marital rape. In D. Finkelhor, R. J. Gelles, G. T. Hotaling, \& M. A. Straus (Eds.), The Dark side of families. Current family violence research (pp. 131-148). Beverly Hills: Sage Publications.

Johnson, I. M., \& Sigler, R. T. (2000). Forced Sexual Intercourse Among Intimates. Journal of Family Violence, 15(1), 95-108. https:/ / doi.org/10.1023/A:1007505621643

Keller, R. (2010). Sociology of Knowledge Approach to Discourse Analysis. A Research Programme for the Analysis of Social Relationships of Knowledge and Politics of Knowledge: Methods for Qualitative Management Research in the Context of Social Systems Thinking. Forum: Qualitative Social Research, 11(3). https://doi.org/10.17169/fqs-11.3.1494

Klein, R. (2012). Responding to intimate violence against women: The role of informal networks. Advances in personal relationships. New York: Cambridge University Press.

Klosterman, K. C., \& Fals-Stewart, W. (2006). Intimate partner violence and alcohol use: Exploring the role of drinking in partner violence and its implications for intervention. Aggression and Violent Behavior, 11(6), 587-597.

Lee, M. Y., \& Greene, G. J. (2004). A Teaching Framework for Transformative Multicultural Social Work Education. Journal of Ethnic And Cultural Diversity in Social Work, 12(3), 1-28. https:// doi.org/ 10.1300/J051v12n03_01

Meuser, M., \& Nagel, U. (2013). Experteninterviews wissenssoziologische Voraussetzungen und methodische Durchführung. In B. Friebertshäuser (Ed.), Handbuch. Handbuch Qualitative Forschungsmethoden in der Erziehungswissenschaft (4th ed., pp. 457-472). Weinheim, München: Beltz Juventa.

Nagy, G., \& Falk, D. S. (2000). Dilemmas in international and crosscultural social work education. International Social Work, 43(1), 49-60. https:/ / doi.org/10.1177/a010520 
Nedelmann, B. (1986). Soziale Probleme und Handlungsflexibilität: Zur Bedeutsamkeit des kulturellen Aspekts sozialer Probleme. In A. Tomaschek (Ed.), Soziale Probleme und Handlungsflexibilität : Entwürfe für berufliches Handeln (pp. 13-42). Freiburg im Breisgau: LambertusVerl.

Parreiro, M. P., \& Rinne, R. (2015). Reading Discourses in the Governance of Educational Trajectories of Youth in Europe. In Parreiro do Amaral, M. P., R. Dale, \& P. Loncle (Eds.), Shaping the Futures of Young Europeans. Education governance in eight European countries (pp. 67-86). Symposium books.

Parrot, A., \& Bechhofer, L. (1991). Acquaintance rape. New York: John Wiley \& Sons.

Reiss, A. J., JR., \& Roth, J. A. (Eds.). (1993). Understanding and preventing violence: Panel on the understanding and control of violent behavior. Washington D.C.: National Academy Press.

Rosenfeld, R. (2009). Oxford Bibliographies Online Datasets. Retrieved from http://www.oxfordbibliographies.com/view/document/obo9780195396607/obo-9780195396607-0050.xml

Schumpeter, J. A. (2008). Capitalism, socialism and democracy (1. Harper Perennial Modern Thought ed.). New York: Harper Perennial Modern Thought.

UN Statistics. (2015). Violence against women: Violence against women is everywhere. Retrieved from https://unstats.un.org/ unsd/ gender/ worldswomen.html

WHO. (2013). Global and regional estimates of violence against women: Prevalence and health effects of intimate partner violence and non-partner sexual violence. Geneva: World Health Organization Department of Reproductive Health and Research. Retrieved from http://www.who.int/reproductivehealth/publications/violen ce/9789241564625/en/index.html

WHO. (2016). Violence against women: Factsheet. Retrieved from http://www.who.int/mediacentre/factsheets/fs239/en/

\section{Excerpt Empirical Material}

Gupta, B., \& Gupta, M. (2013). Marital Rape: - Current Legal Framework in India and the Need for Change. Galgotias Journal of Legal Studies (GJLS), 1(1), 16-32.

Nef, S. (Spring time, 2013). Transkripts and Analysis: Perceptions and interventions. Interviews with Experts. India. 
Pandey, P. K. (2013). Marital Rape in India - Needs Legal Recognition. SSRN Electronic Journal. Advance online publication. https:// doi.org/10.2139/ssrn.2290027

PRS. (2013). Justice Verma Committee Report Summary: Report Summaries. Retrieved from http:// www.prsindia.org/ parliamenttrack/report-summaries/justice-verma-committeereport-summary-2628/

Sec. 375. Rape. The Indian Penal Code (Law Commission of India / Ministry of Law \& Justice 1973).

The Indian Express (2013a, January 2). The holy writ. Retrieved from http://archive.indianexpress.com/news/the-holywrit/1052979/

The Indian Express (2013b, March 21). The burden of proof: Can we trust a state like ours to investigate and decide upon sexual relations between man and wife? Retrieved from http://indianexpress.com/ article/opinion/columns/theburden-of-proof/

The Male Factor. (2013). Feminist advocacy of marital rape - a hollow promise of women empowerment. Blog. Retrieved from https:// themalefactor.com/2013/02/09/feminist-advocacy-ofmarital-rape-a-hollow-promise-of-women-empowerment/

Times of India (2012a, December 4). Forced sex after marriage not rape: Court. The Times of India Mumbai, p. 7. Retrieved from http://epaper.timesofindia.com/Repository/getFiles.asp?Style $=$ OliveXLib:LowLevelEntityToPrint_TOINEW\&Type=text $/ \mathrm{htm}$ 1\&Locale=english-skin-

custom\&Path=TOIM/2012/12/04\&ID=Ar00705

Times of India (2012b, December 24). Women not safe in their bedrooms too -. Retrieved from http:// timesofindia.indiatimes.com/ city/ bengaluru/Women-notsafe-in-their-bedrooms-too/articleshow/17738428.cms

Times of India (2013a, January 14). Marital rape: Dirty linen that needs to be aired - Times of India. The Times of India. Retrieved from

http://timesofindia.indiatimes.com/city/mumbai/Maritalrape-Dirty-linen-that-needs-to-beaired/articleshow/18011780.cms 
Times of India (2013b, February 20). Govt in no mood to criminalize marital rape. Times of India. Retrieved from http:// timesofindia.indiatimes.com/india/Govt-in-no-mood-tocriminalize-marital-rape/articleshow/18583796.cms

Times of India (2013c, March 3). Women organizations slam move on marital rape -Times of India. The Times of India. Retrieved from

http:/ / timesofindia.indiatimes.com/city/vadodara/Womenorganizations-slam-move-on-marital-rape/ articleshow/ 18782107.cms?

Verma, J. S., Seth, L., \& Subramanium, G. (2013). Report of the Committee on: Amendements to Criminal Law. Retrieved from http:// www.prsindia.org/parliamenttrack/reportsummaries/ justice-verma-committee-report-summary-2628/ 